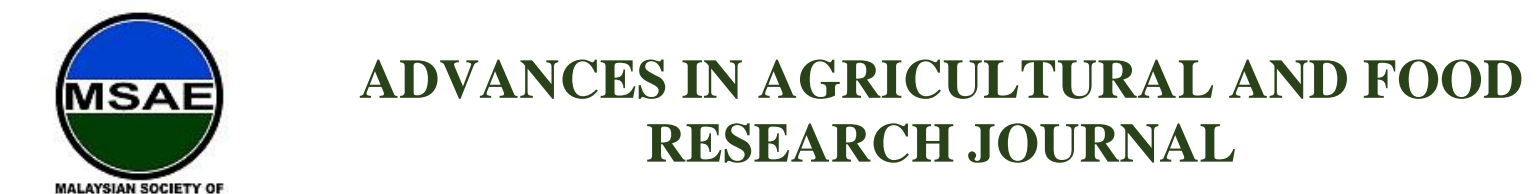

HH PUBLISHER

Original Research Article

\title{
Evaluation of Different Designs of Isolated Cells to Raise Single Rice Seedlings for SRI Mechanized Transplanting
}

\author{
Mohd Amin Mohd Soom ${ }^{1 *}$, Azwan Awang ${ }^{1}$, Mohamadu Boyie Jalloh ${ }^{1}$ \\ ${ }^{1}$ Crop Production Program, Faculty of Sustainable Agriculture, Universiti Malaysia Sabah, Locked Bag No.3, \\ 90509 Sandakan, Sabah, Malaysia \\ *Corresponding author: Mohd Amin Mohd Soom, Crop Production Program, Faculty of Sustainable \\ Agriculture, Universiti Malaysia Sabah, Locked Bag No.3, 90509 Sandakan, Sabah, Malaysia; \\ mohd.amin@ums.edu.my
}

\begin{abstract}
Numerous benefits of the system of rice intensification (SRI) have been documented since SRI was popularized 30 years ago. To date, more than 58 rice growing countries are practicing SRI, covering around 4 million ha of paddy fields and involving more than 10 million farmers. Many paddy farmers shy away from practicing SRI due to extreme labour endurance and number of labors required, especially during transplanting and frequent weeding. The manual transplanting technique to ensure proper root establishment of the seedlings, makes SRI less appealing to many paddy farmers. Furthermore, the transplanting shock is a problem arises from manual transplanting technique needs to be solved that resulted to damaged roots causing delays in crop establishment and reducing productivity. Mechanized transplanting of the young single seedlings into the paddy fields at a wider plantation area eliminates drudgery and enables better exposure to sunlight, water, air, and nutrients. This paper presents a solution to overcome the problem of transplanting shock and the back-breaking manual transplanting, which was achieved by containing the roots of each seedling in a grid of isolated cells. Several designs of the isolated cells to contain the root system were fabricated and tested. These include using aluminum square cells, polyvinyl chloride pipe circular cells, biodegradable grid cells, biodegradable conical capsules, and germinated seeds sowed in a grid without isolated cells. The typical grid cell size was $15 \mathrm{~mm}$ by $15 \mathrm{~mm}$ with a depth of each cell varied from $40 \mathrm{~mm}$ to $60 \mathrm{~mm}$. The most promising design was one with single seedlings raised in bio-degradable capsules arranged close together to fit the conventional rice seedling tray of $300 \mathrm{~mm}$ by $600 \mathrm{~mm}$ and can accommodate 684 capsules per tray. Upon reaching 2-3 leaf stage, the seedlings with undisturbed roots are ready to be transplanted into the paddy fields using the currently available rice transplanters.
\end{abstract}

Keywords: SRI; paddy; mechanized transplanting; bio-degradable capsules; nursery tray

Received: $14^{\text {th }}$ October 2020

Received in revised form: $10^{\text {th }}$ December 2020

Accepted: $11^{\text {th }}$ December 2020

Available Online: $24^{\text {th }}$ December 2020
Citation: Mohd Soom MA, Awang A., Jalloh M. Evaluation of different designs of isolated cells to raise single rice seedlings for SRI mechanized transplanting. Adv Agri Food Res J 2021; 2(1): a0000146. https://doi.org/10.36877/aafrj.a0000146 


\section{Introduction}

The average world rice production and similarly for Malaysia is around 4t/ha. However, the system of rice intensification (SRI) practices has shown that yields of more than 20t/ha are not impossible to achieve (Uphoff, 2015). To bridge the gap between the potential and the current productivity, we should learn from the success stories and experiences of other rice growing countries. To date, more than 58 rice producing countries covering around 4 million ha of paddy fields and involving more than 10 million farmers are practicing SRI. The numerous benefits of SRI have been well documented by many authors since SRI was popularized some 30 years ago (Uphoff, 2006; Uphoff, 2015).

Some commonly cited benefits include higher grain yield and better rice quality as a result of the proliferation of roots from single seedlings, stronger stalks, more established tillers, and climate change readiness. Raising single seedlings for SRI only uses $10 \%$ of the seeds, otherwise normally used for other ways of planting rice. The often-quoted rice nursery figures for the amount of seeds needed in $\mathrm{kg}$ of seeds per ha of paddy area are $50 \mathrm{~kg}$ for conventional nursery bed, $25 \mathrm{~kg}$ for the conventional tray, and $5 \mathrm{~kg}$ for SRI nursery tray (Zubairu et al., 2015). Other advantages are water saving, enriched soil from the addition of organic matter, while using less agro-chemicals and less water. However, the disadvantages of SRI are labor intensivity. Back breaking manual transplanting, the awkward postures assumed, and exposure to heat are some of the risk factors that reduce the productivity and efficiency of the farmers. Hence there is a need to mechanize those operations in order to reap the well documented benefits from SRI.

One of the factors that contribute to higher rice grain production under SRI is transplanting at a very young age. This is based on Katayama tillering model, which explains that a large number of tillers can be produced, when rice is transplanted at an early age (Laulanié , 2011). The maximum number of tillers produced by the rice plant is inversely proportional to the length of the phyllochron, which is dependent upon the extent of stresses (Katayama, 1951; Veeramani et al., 2012; Uphoff, 2006). Wider spacing, availability of solar radiation, medium temperature, soil aeration, and nutrient supply promote shorter phyllochrons which increase the number of tillers (Anon, 2004; Veeramani et al., 2012). De Laulanie found that if the rice seedlings are transplanted later than the third phyllochron, the resulting plant will lose all of the incoming tillers from this first row of tillers, which represents about $40 \%$ of the total tillers and that any further delay in transplantation leads to a bigger loss of tillers (Laulanié, 2011). An Indonesian paddy farmer has obtained a maximum of 223 fertile tillers from a single seedling; that is upon completion of its $14^{\text {th }}$ phyllochrons of growth before vegetative growth was replaced by grain reproduction (Uphoff et al., 2009).

Rice seedlings raised in the conventional nursery trays tend to have interconnected roots formed into a mat. Transplanting 3-4 weeks old seedlings with 2 or 3 plants per hill, manually or using a transplanting machine damages the roots and the plants experiences 
transplanting shock. The plant roots are the "mouth" of the plant, where the plant takes in its food. If these roots are exposed to air, sun, or rough handling, many of them will be destroyed. The root hairs, which can hardly be seen with the human eye, absorb nutrients for the plants. If root hairs are damaged or shocked in transplanting, they stopped absorbing food for the plant, and the plant growth is slowed down. Transplanting shock is a term that refers to a number of stresses occurring in recently transplanted seedlings. It involves failure of the plant to root well; consequently, the plant becomes poorly established in the paddy field. The bubble tray nursery developed by International Rice Research Institute (IRRI) follows the modified mat system to develop seedlings with root balls (Karthik et al., 2018). Seedlings grown in bubble trays experience less transplanting shock. However, each root ball has 3-4 seedlings. At 12-15 days old, seedlings are broadcasted in the field. To do this, the farmers have to prepare 750 trays per hectare of paddy and raise seedlings on plastic trays of $59 \mathrm{~cm}$ x $34 \mathrm{~cm}$ with 434 embedded holes (Karthik et al., 2018).

In SRI, the manual transplanting of the delicate young single seedlings is an attempt to reduce transplanting shock. One way to minimize transplanting shock is to have strong, healthy, growing seedlings, and placing the seedlings at intersection points carefully on the paddy soil surface at a shallow position (less than $1.5 \mathrm{~cm}$ deep) with the roots forming an ' $\mathrm{L}$ ' shape. After placing the seedling at the right position, roots are covered with soil on the extended roots with fingers. When a seedling is transplanted carefully at the initial growth stage, the stress of root damage caused during uprooting is minimized following a rapid growth with short phyllochrons. However, this manual transplanting is not easily done, resulting in roots forming a ' $\mathrm{J}$ ' shape, thereby needing time to get established (Uphoff, 2015).

\subsection{Mechanized Transplanting of Single Rice Seedlings without Root Interconnection}

There is a need to eliminate the drudgery of manual transplanting of delicate young seedlings and at the same time, eliminate transplanting shock. The idea was to promote wider adoption of SRI through mechanized transplanting covering a larger area in a shorter time that increases productivity and ensures the food security of the country. Many attempts have been made on the suitable ways to mechanize transplanting of the young, single rice seedlings for SRI (Sharif et al., 2010; Dhananchezhiyan et al., 2013; Ibrahim \& Ismail, 2014; Shamshiri et al., 2019; Imran et al., 2019). Most researchers were looking at finding a suitable machine to do job of transplanting the delicate young single seedlings, but less concerned about root damage by the mechanical finger of the transplanter. Our own previous studies on raising single seedlings (SS) have produced a tray design for single seedlings without interconnected roots that is practical for manual transplanting (Zubairu et al., 2015; Wayayok et al., 2015; Zubairu et al., 2018). The design of the Single Seedling Nursery Tray (SSNT) was filed for Malaysian patent (PI2013700745) and International Patent WIPO (PCT) (International Publication No. WO2014182151AI). However, even though the tray design was able to produce single seedlings with undisturbed roots, there was a need for a new design of a suitable transplanting machine. Upon considering various options, we decided on using the currently available, widely used commercial transplanter as the carrier of the nursery 
seedling mat with isolated single seedling cells. Hence, the aim of this study was to investigate possible ways to raise single rice seedlings with undisturbed roots, while transplanting at 2-3 leaf stage using the commonly used rice transplanting machine with seedlings in isolated cells fitted into the conventional rice nursery tray. The specific objective of this study was to evaluate various designs of isolated cells to produce single rice seedlings without interconnected roots suitable for SRI mechanized transplanting.

\section{Materials and Methods}

Five newly isolated cell tray designs were fabricated and tested in this study. After attempting with rigid isolated cells, various bio-degradable materials were selected to form the grid cells and capsules in the conventional nursery tray. Various growing media were also chosen together with fibrous coir-pith at the base of the tray so that the roots will form into a mat. The new designs of the isolated cells to contain the root system include using aluminum square cells, polyvinyl chloride pipe (PVC) circular cells, biodegradable grid cells, biodegradable conical capsules, and germinated seeds sowed in a grid without isolated cells. Detailed descriptions of the design, fabrication, and evaluation of the new Single Seedling Rice Nursery (SSRN) Tray can be found in the Universiti Malaysia Sabah (UMS) Final Year Student Project Reports (Amin et al., 2016). Some of the selected designs, all fitted in the conventional rice nursery tray, are shown in Figures 1 and 2.

(a) Aluminium square cells — 14 mm X 14 mm X 35 mm; 14 mm X 14 mm X 45 mm; with compost.

(b) PVC pipe circular cells - $15 \mathrm{~mm}$ diameter by $45 \mathrm{~mm}$ depth; with biochar, top soil and compost.

(c) Biodegradable Grid cells - $15 \mathrm{~mm} \mathrm{X} 15 \mathrm{~mm}$ X $30 \mathrm{~mm} ; 15 \mathrm{~mm} \mathrm{X} 20 \mathrm{~mm} \mathrm{X} 30 \mathrm{~mm}$; biochar, compost.

(d) Grid without isolated cells — $15 \mathrm{~mm}$ X $20 \mathrm{~mm}, 20 \mathrm{~mm} \mathrm{X} 20 \mathrm{~mm}$; with biochar and compost.

(e) Biodegradable conical capsules - $20 \mathrm{~mm}$ and $15 \mathrm{~mm}$ diameter X $40 \mathrm{~mm}$; with compost and coir-pith. 


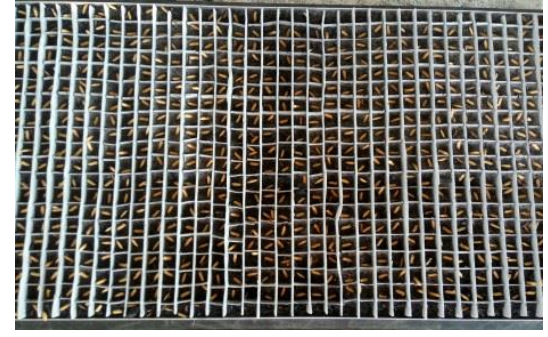

(a)

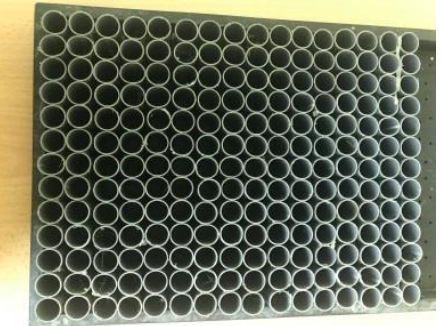

(b)

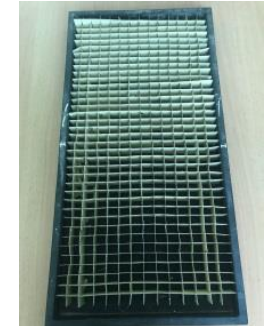

(c)

Figure 1. Rigid isolated cells made from various materials fitted into the conventional rice nursery tray (600 mm x $300 \mathrm{~mm}$ x 30mm); (a) aluminium grid cells, (b) PVC pipe circular cells, (c) biodegradable grid cells.

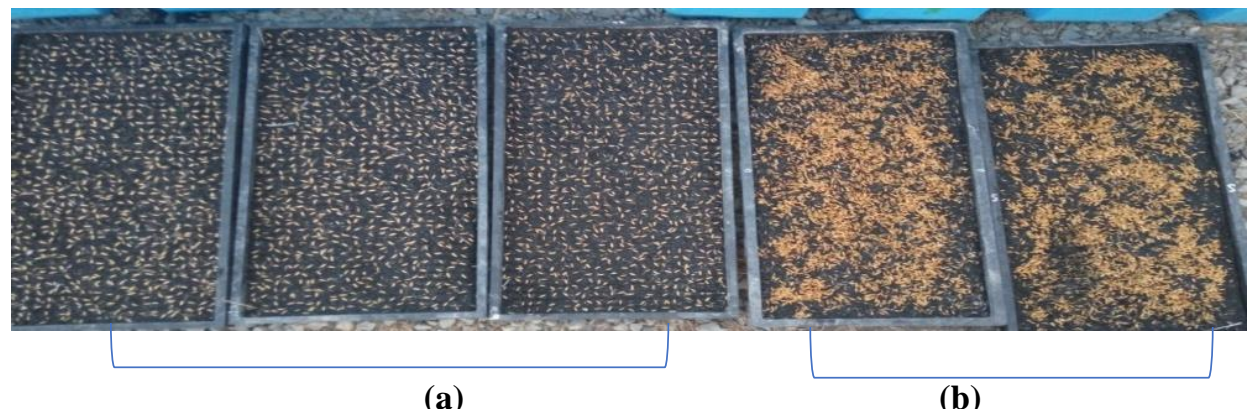

Figure 2. Single seedlings raised in the conventional rice nursery tray; (a) Careful placement of the germinated seeds in grids with spacing between the seeds; (b) the conventional practice of raising seedlings in rice nursery trays with a lot more seeds.

\section{Results}

All attempts to produce single seedlings with isolated cells were successful. However, the rice husk bio char and top-soil plus composted manure were found to be difficult to be removed from each respective cells. The desired growing medium should be able to slide out from the cells easily. In this case, the media remained intact in the cells until transplanted.

The seedlings produced from both aluminum trays that contain 800 isolated square cells (14 mm x14 mm) with different depths of $35 \mathrm{~mm}$ and $45 \mathrm{~mm}$ were compared at 12 days after seeding (DAS). There were no obvious differences among them, suggesting that $35 \mathrm{~mm}$ depth was sufficient. The drawbacks of using trays with $45 \mathrm{~mm}$ depth were increased cost of production and increased difficulties to transplant the seedlings using the currently available rice trans planter. The growth performance of single rice seedlings showed no obvious differences initially between single seedlings with disturbed and undisturbed roots.

There was no significant difference during the vegetative growth among the rice plants for seeds that were sown in the conventional trays under flooded condition for 12 days at different densities. The interconnection of roots was not well established for the 800 seeds tray that needed to be handled very carefully, since the mat can be broken easily (Figure 3). 
On the other hand, the 380-PVC isolated circular cells tray at $45 \mathrm{~mm}$ depth was unsuitable for mechanical transplanting as the rooting networks were not sufficient to form a mat at 12 DAS. The root mat of the control tray was only partially sufficient at the bottom of the tray. This indicated that the 12 DAS seedlings might not be suitable for mechanical transplanting due to unsaturated root networks to provide enough rigidity for the mat and to offer suitable growth environment.

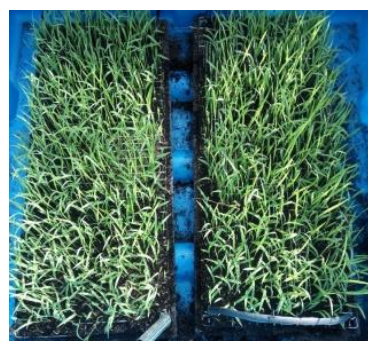

(a)

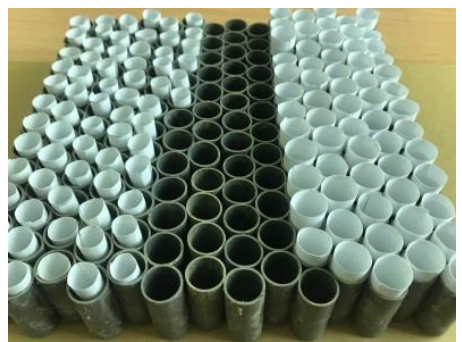

(b)

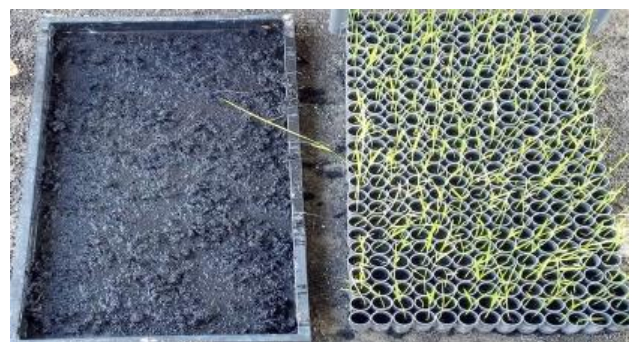

(c) (d)

Figure 3. Seedlings raised in isolated cells of $45 \mathrm{~mm}$ depth could not produce enough root networks to form a mat; (a) 12 DAS single seedlings produced in the 800 isolated square cells in aluminum trays; (b) PVC circular cells and biodegradable capsules; (c) conventional rice nursery tray, $60 \mathrm{~cm}$ x $30 \mathrm{~cm}$ x $3 \mathrm{~cm}$, and (d) Seedlings raised in the 380 PVC pipe circular isolated cells.

The germinated seeds raised in isolated cells up to two weeks old cannot be formed into sufficient root networks to provide enough rigidity for a mat and to offer a suitable growth environment. Subsequently, a thin layer of fibrous coir pith was added at the bottom of the nursery tray. Figure 4 shows seedlings raised in the bio-degradable conical capsules arranged in a $15 \mathrm{~mm}$ x $15 \mathrm{~mm}$ grid with depths varied from 40-60 mm. The hand-made capsules were placed in each grid cell created by using cotton thread. The capsules were connected by applying some form of glue so that the capsules were kept upright for filling of the soil growing media and sowing the germinated seeds. A nicely formed mat was obtained by putting a thin layer of fibrous coconut coir pith at the bottom of the tray. When transplanted, there were some damages occurrence to the bottom roots, but the top $40 \mathrm{~mm}$ of roots and soil were intact, hence reducing transplanting shock. 


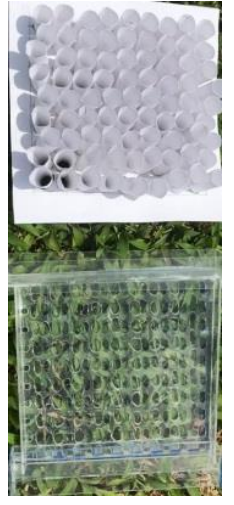

(a)

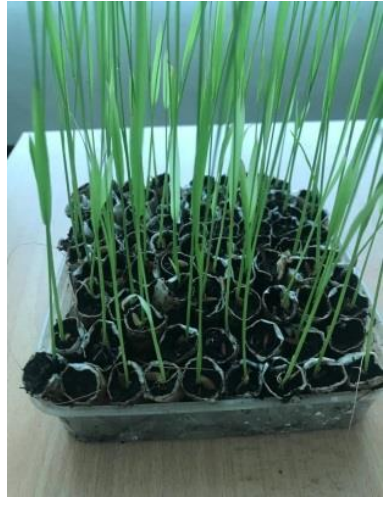

(b)

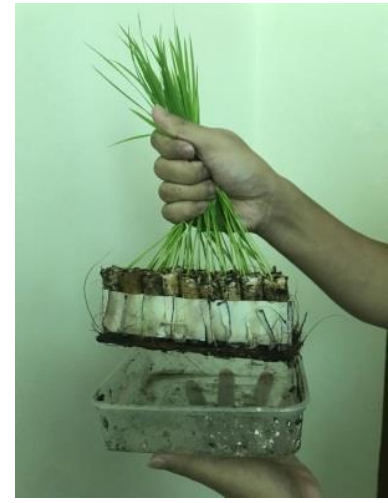

(c)

Figure 4. (a) Bio-degradable conical capsules arranged in a $15 \mathrm{~mm}$ x $15 \mathrm{~mm}$ grid (top) with sliding seed placement plates (bottom), (b) single seedlings in biodegradable capsules ready for transplanting, (c) sufficient root network obtained by placing a layer of fibrous coir pith at the bottom of the tray.

The earlier results of the study have led to new innovation in rice cultivation, which was a rice nursery tray with bio-degradable conical capsules arranged in a $15 \mathrm{~mm}$ x $15 \mathrm{~mm}$ grid. The size of the conical capsule was $15 \mathrm{~mm}$ top diameter, $10 \mathrm{~mm}$ bottom diameter, and $40 \mathrm{~mm}$ depth. A total of 684 conical capsules can be fitted into the conventional rice nursery tray measuring $60 \mathrm{~cm}$ x $30 \mathrm{~cm}$ x $3 \mathrm{~cm}$ (aka SRICAPS684). The capsules were connected to each other by tiny connectors glued to each capsule to keep them upright for filling the soil growing media and sowing the germinated rice seeds.

A summary of the production and use of SRICAPS684 Tray, as shown in Figure 5 is as follows:

(a) Each conical capsule was made from a bio-degradable material, $15 \mathrm{~mm}$ top diameter, 10 $\mathrm{mm}$ bottom diameter, and $40 \mathrm{~mm}$ depth. Each capsule was connected to the others by a small strip of the same material glued together for the capsules to be held upright for filling in the growing media.

(b) A total of 684 capsules were fitted into the standard conventional rice nursery tray measuring $600 \mathrm{~mm}$ long, $300 \mathrm{~mm}$ wide, and $30 \mathrm{~mm}$ deep.

(c) After filling the capsules with growing media, the germinated rice seed was sown in each capsule using the sliding seed placement plates.

(d) Germinated seeds were grown into 2-3 leaf seedlings before transplanting into the paddy field.

(e) A healthy 2-leaf stage rice seedling with undisturbed roots, all contained within the capsule were ready for transplanting. At the 3-leaf stage, roots were longer and grow out of the capsules. 
(f) Results of field trials on planting the single seedlings raised in conical capsules could produce up to 50 panicles, which is more than twice the typical rice yield of Sabah paddy farmers.

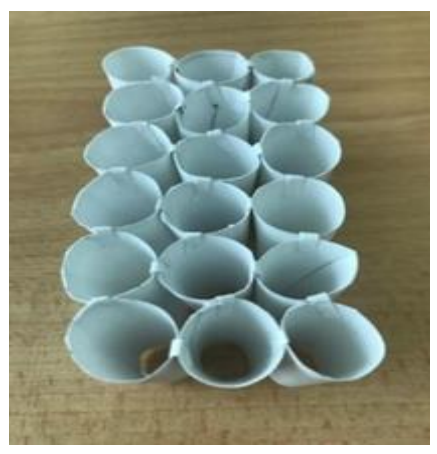

(a)

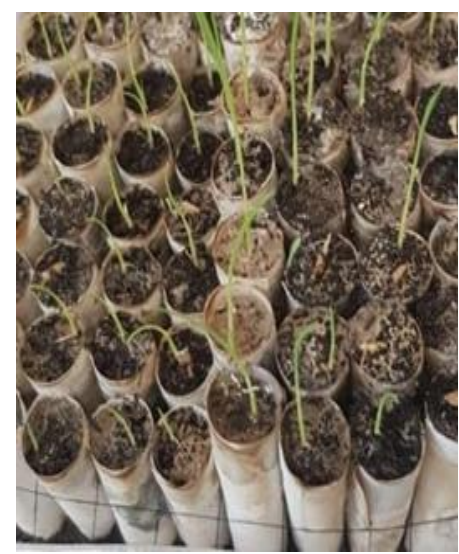

(d)

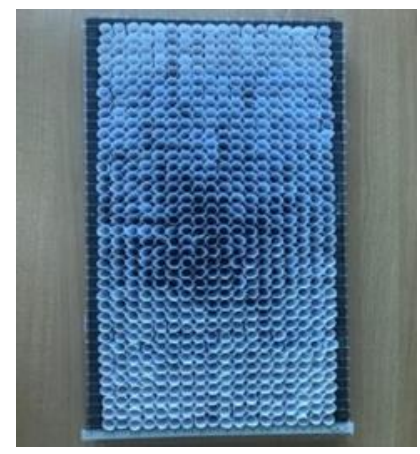

(b)

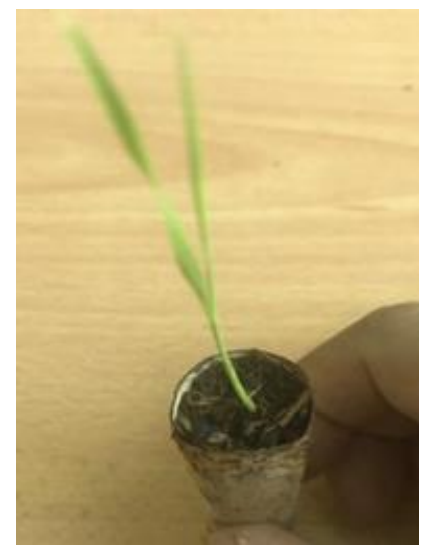

(e)

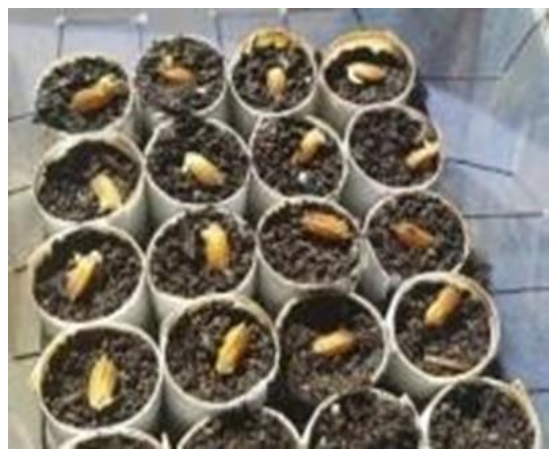

(c)

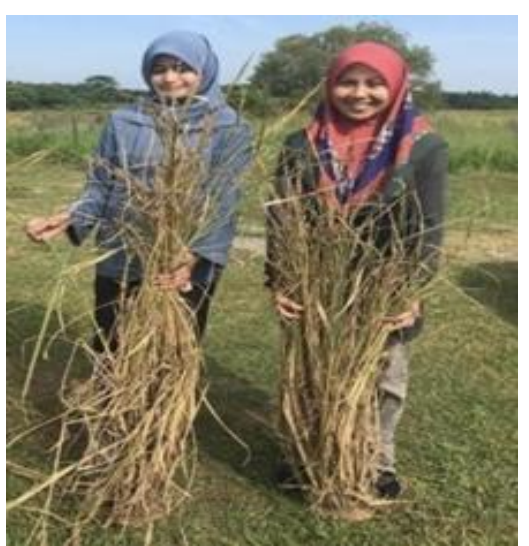

(f)

Figure 5. The SRICAPS684 Tray — single seedling capsules for SRI mechanized transplanting.

Upon reaching a 2-3 leaf stage (Figure 5e), the SRICAPS684 with or without a root mat formation was ready to be transferred to the planting machine for transplanting into the paddy field. The bio-degradable capsules were strong enough to withstand the impact of the rotating mechanical finger of the trans-planter to pick or push the single seedlings in the capsules into the saturated puddled paddy soil. The capsules lasted another one to two weeks under wet and dry conditions before disintegrating completely, thus allowing the proliferation of the SS rooting system to feed the seedlings with nutrients necessary for maximum number of phyllochrons.

Field tests showed that the SRI single seedling capsules were able to produce healthy plants, yielding up to 50 panicles or more (Figure 5f), which is 2-3 times more yield than the current standard management practice. This study has shown a promising result of the higher production capability of SRICAPS684 as a new way of raising strong, healthy young seedlings with undisturbed roots during transplanting, using the conventional 
rice nursery tray and the readily available rice trans planter. However, mass production was required by manufacturing the bio-degradable capsules that can fit into the conventional rice nursery trays.

\section{Discussion}

The current practice of using a rice transplanter to transplant rice seedlings involved transplanting 3-4 week-old seedlings with 2-3 seedlings per hill. At 3-4 weeks, seedlings were sown together in the conventional nursery tray forming a mat of interconnected roots and easily transferred from the trays to the transplanter platform. But mechanical transplanting cause damage to roots. The stress of transplanting shock endured by the seedlings during transplanting required time to establish good growth and produce high yield. However, according to Laulanie (2011), the developer and pioneer of SRI, higher yields are possible only if transplanting is done with seedlings of less than 2 weeks old.

In this study, alternative tray designed to raise single seedlings from isolated cells did not produce the intended network of roots to form a mat, especially at 2-week old. However, a mat, if required, was still possible to be formed with the addition of fibrous coir pith at the base of the tray.

A tray of isolated cells in the form of bio-degradable conical capsules designed, fabricated and tested in this study can be used to raise single rice seedlings irrespective of whether to be transplanted manually or mechanically. The roots and the growing media were intact during transplanting and the bio-degradable capsule with time was disintegrated into the paddy soil. Without the mat and broken roots during transplanting, the seedlings had less stress to be achieving its maximum potential yield and productivity.

Even though the intended end product of this study was a tray for mechanized transplanting of single rice seedlings, SRICAPS684 can also be used as a micro pot for raising any crop seedling and later on planting the seedlings together with the bio-degradable capsules without disturbing or damaging the roots of the seedlings, hence avoiding transplanting shock. Future field trials for SRI using manufactured SRICAPS684 will accomplish more useful results due to the elimination of transplanting shock. However, presently, there is a manufacturing need for mass production. Subsequently, there is also a need for the manufacture of the "sliding seed placement plates" to accompany the SRICAPS684 trays in order to hasten the placement of the germinated seeds into the capsules.

\section{Conclusions}

The drudgery and labor-intensive manual transplanting of single rice seedlings for SRI can be avoided with mechanized transplanting. However, there is also a need to eliminate transplanting shock in order to achieve higher productivity. The SRICAPS684 tray was successfully developed to raise single seedlings in isolated cells. This technology provides SRI paddy farmers with a new design of nursery tray for mechanized transplanting of the 
fragile young seedlings into their paddy fields using the existing commercially available rice transplanting machine. Transplanting single seedlings at 2-3 leaf stage with the soil growing media intact and undisturbed roots promoted the maximum growth of phyllochrons before reaching the reproductive stage for grain production. Seedlings raised in the new tray resulted to the highest grain yield from maximum number of productive tillers resulting from the positive factors, which influence phyllochrons. These were early transplanting with minimum root stress during transplanting, wide spacing, planting single seedlings per hill, weeding with a rotating hoe, and alternate aerobic and anaerobic soil conditions (wetting and drying). The transplanting of single seedlings with the soil growing media and roots intact allows rice plants to grow better and produce more. Ultimately, with mechanized transplanting covering a wider area in a shorter time, the paddy farmers can then reap the many benefits of SRI paddy cultivation method towards achieving our food security and improved livelihood of the farmers.

Acknowledgements: The participation of many final year students and field staff of FPL UMS in the project is highly appreciated and acknowledged.

Funding: No external funding was provided for this research. The authors wish to thank Universiti Malaysia Sabah for the financial suport for the project from the UMS-SBK grant No. SBK0272-STWN-2016.

Conflicts of Interest: The authors declare no conflict of interest, and also the funders had no role in the design of the study; in the collection, analyses, or interpretation of data; in the writing of the manuscript, or in the decision to publish the results.

Patents: The work reported in this manuscript is being considered for patent filing.

\section{References}

Amin, M. S. M., Loan, L. W., Nia'amad, N. M., et al. (2016). Towards mechanized transplanting of single seedlings for system of rice intensification. In Proc. of Regional Conference on Sustainable Agriculture, Universiti Malaysia Sabah.

Food, Agriculture and Development. (n.d.). How to help rice plants to grow better and produce more: Teach yourself and others. Retrieved from http://sri.ciifad.cornell.edu/extmats/engmanual.pdf.

Dhananchezhiyan, P., Duraira, C. D., \& Parveen, S. (2013). Development of nursery raising technique for system of rice intensification machine transplanting. African Journal of Agricultural Research, 8(29), 3873-3882.

Ibrahim, B., \& Ismail, W. I. W. (2014). Development of System Rice Intensification (SRI) paddy transplanter. Asian Journal of Agricultural Sciences, 6(2), 48-53.

Imran, M. S., Abdul Manan, A. N. M., Khalil, S., et al. (2019). The transplanter tools for small paddy fields: System of Rice Intensification (SRI) compliance. IOP Conference Series: Materials Science and Engineering. Joint Conference on Green Engineering Technology \& Applied Computing 2019 4-5 February 2019, Eastin Hotel Makkasan, Bangkok, Thailand.

Karthik, A.V., Akshay, S. Bhat1., Mahesh Kumar, V. B., et al. (2018). Design and fabrication of hybrid rice seedling transplanter. International Journal of Computational Engineering Research (IJCER), 8(2), 26-36.

Laulanié, H. (2011). Intensive rice farming in Madagascar. Tropicultura, 29(3), 183-187.

Shamshiri, R. R., Ibrahim, B., Balasundram, et al. (2019). Evaluating system of rice intensification using a modified transplanter: A smart farming solution toward sustainability of paddy fields in Malaysia. International Journal of Agricultural and Biological Engineering, 12(2), 1-14. 
Sharif, A. (2010). Technical adaptations for mechanized SRI production to achieve water saving and increased profitability in Punjab, Pakistan. Paddy and Water Environment, 9(1), 111-119.

Uphoff, N (2006). The development of the system of rice intensification. International Development Research Centre, Ottawa.

Uphoff, N. (2007). Farmer innovations improving the system of rice intensification. Jumal Tanah dan Lingkungan, 9(2), 45-56.

Uphoff, N., Anas, I., Rupela, O. P., et al. (2009). Learning about positive plant-microbial interactions from the System of Rice Intensification (SRI). Aspects of Applied Biology, 98, 29-53.

Uphoff, N. (2015). The System of Rice Intensification (SRI). Retrieved from http://sri.cals.cornell.edu/aboutsri/SRI_FAQs_Uphoff_2016.pdf

Veeramani, P. R., Singh, D., \& Subrahmaniyan, K. (2012). Study of phyllochron-System of Rice Intensification (SRI) technique. Agricultural Science and Research Journal, 2(6), 329-334.

Wayayok A, Mohammed, U., Zubairu, U. B., et al. (2015). Comparative study on the performance of rice seedlings raised by single seedling nursery tray method and conventional system. American Journal of Plant Biology, 2(1), 1-4

Zubairu, U. B., Wayayok A., Amin, M. S. M., et al. (2015). Single seedling nursery tray: an innovative breakthrough to quality seedling raising technique for SRI transplanting machine. Research Journal of Applied Sciences, Engineering and Technology, 10(11), 1258-1265.

Zubairu, U. B., Graham, W. V., Wayayok, A., et al. (2018). SRI single seedling transplanting implement: An innovative technique to challenges on SRI planting and spacing techniques. Food Research, 3(2), 167-173.

Copyright (C) 2020 by Mohd Soom MA et al. and HH Publisher. This work is licensed under the Creative

Commons Attribution-NonCommercial 4.0 International Lisence (CC-BY-NC4.0) 